\title{
Class-II and IL 2 receptor positive cells in the pancreas of NOD mice
}

\author{
A.Signore ${ }^{1,6}$, A.Cooke ${ }^{2}$, P. Pozzilli ${ }^{3,6}$, G. Butcher ${ }^{4}$, E. Simpson ${ }^{5}$ and P.C. L. Beverley ${ }^{1}$ \\ ${ }^{1}$ ICRF, HTIG, Faculty of Clinical Sciences, University College London, ${ }^{2}$ Department of Immunology, The Middlesex Hospital, \\ Medical School, and ${ }^{3}$ Department of Diabetes and Immunogenetics, St. Bartholomew's Hospital, London, UK; \\ ${ }^{4}$ AFRC, Institute of Animal Physiology and Genetic Research, Cambridge Research Station, Babraham Hall, Cambridge and \\ ${ }^{5}$ Transplantation Biology Center, Clinical Research Center, Harrow, Middlesex, UK; \\ ${ }^{6}$ Cattedra Endocrinologia (I), Clinica Medica (II), University of Rome "La Sapienza", Rome, Italy
}

\begin{abstract}
Summary. The aberrant expression of Class-II molecules on pancreatic B cells in Type 1 (insulin-dependent) diabetes is still a matter of debate. In order to verify if Class-II molecules are expressed on islet cells in the NOD mouse we have studied 21 female mice of different ages ( 5 to 22 weeks). Serial cryostat pancreas sections were stained with monoclonal rat antibodies against Class-II antigens (P7/7) and the IL2 receptor (AMT-13). Our results show no Class-II expression by endocrine cells at any age, whereas about $25-32 \%$ of mononuclear cells infiltrating the islets were Class-II posi-
\end{abstract}

tive, and only $6-9 \%$ were IL 2 receptor positive. No staining, except of occasional tissue macrophages, was observed in the pancreas of BALB/c, CBA or B10.SCSN mice. Our data are in contrast with those recently published and therefore the reality of expression of Class-II molecules by islet cells of NOD mice should be viewed with caution.

Key words: Type 1 (insulin-dependent) diabetes, Class-II molecules, IL2 receptor, NOD mice, insulitis, activated lymphocytes, lymphocyte subsets.
Type 1 (insulin-dependent) diabetes mellitus is an immune-mediated disease characterised both in humans and animal models by pancreatic lymphocytic infiltration [1-3]. In the latter the presence of islet cell antibodies has been reported together with other autoantibodies $[4,5]$. Uncertainty persists concerning the extent and importance of aberrant expression of Class-II antigens on pancreatic B cells. This has been reported in newly diagnosed diabetic patients $[6,7]$ as well as in prediabetic $\mathrm{BB} / \mathrm{E}$ rats [8]. A recent report [9] showed Class-II expression on $\mathrm{B}$ cells of diabetes prone NOD mice but also of non-diabetic B10.GD and BALB/c mice. Other reports suggest that Class-II antigens in mice are expressed only on monocytes, B lymphocytes and a few epithelial cells $[10,11]$ but not on islet cells. In humans these antigens are also expressed on activated $\mathrm{T}$ lymphocytes and are considered as a marker for $T$ cell activation [12]. In rodents, however, their expression is much less frequent among lymphocytes [13].
We have investigated the expression of Class-II molecules on pancreatic islet cells in NOD and other non-diabetes prone strains of mice using the P7/7 $\mathrm{MAb}$, while an anti-IL2 receptor (IL2R) MAb was used to detect activated $\mathrm{T}$ lymphocytes infiltrating the islets.

\section{Materials and methods}

\section{Animals}

Twenty-one female NOD mice $\left(\mathrm{K}^{\mathrm{d}}, \mathrm{I}-\mathrm{A}^{\mathrm{NOD}}, \mathrm{D}^{\mathrm{b}}[14]\right)$ were part of a colony kindly donated by E.H. Leiter (The Jackson Laboratory, Bar Harbor, Me, USA). They were killed at the age of 5, 9, 13, 17 and 22 weeks, the pancreata removed and immediately frozen in liquid nitrogen.

Five female BALB/c $\left(\mathrm{H}-2^{\mathrm{d}}\right)$, two B 10.SCSN $\left(\mathrm{H}-2^{\mathrm{b}}\right)$ and two CBA $\left(\mathrm{H}-2^{\mathrm{k}}\right)$ mice were used as control animals.

Fig. 1 A-D. Immunoperoxidase staining of cryostat pancreas sections using P7/7 (A, B, C) and AMT-13 MAb (D). A An intact islet of a 5-week old NOD mouse. There are only a few tissue macrophages stained (arrows) $(\times 225)$. B Infiltrated islet of a 22 -week-old NOD mouse. Most of the mononuclear cells infiltrating the edge of the islet are Class-II positive but no staining is detectable on islet cells ( $\times 450)$. C An intact islet of a 15-week old BALB/c mouse. Staining is only detectable in a few tissue macrophages (arrows) $(\times 225)$. D Infiltrated islet of a 22-week-old NOD mouse. Stained cells are activated lymphocytes expressing IL2 receptors $(\times 360)$ 

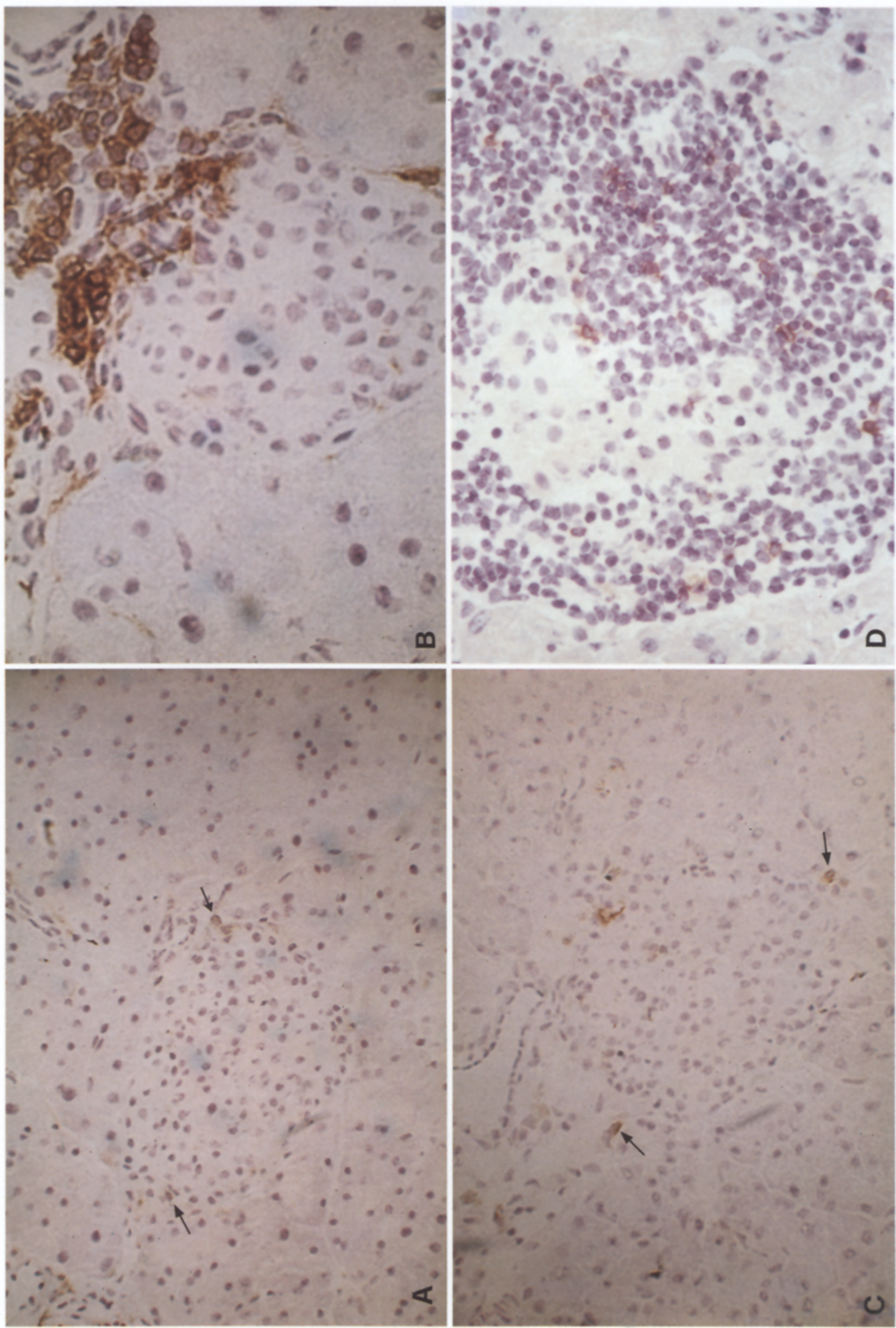
Table 1. Percentage of positive cells in the pancreas of NOD mice of different ages

\begin{tabular}{lccccc}
\hline \multicolumn{1}{l}{ Age (weeks) $5^{\mathrm{a}}$} & \multicolumn{1}{c}{$9^{\mathrm{b}}$} & $13^{\mathrm{c}}$ & \multicolumn{1}{l}{$17^{\mathrm{b}}$} & \multicolumn{1}{c}{$22^{\mathrm{c}}$} \\
\hline IL2R+ & $8.5 \pm 2.1$ & $6.9 \pm 3.0$ & $5.9 \pm 1.8$ & $6.0 \pm 2.2$ & $7.9 \pm 4.6$ \\
$\begin{array}{l}\text { (AMT-13) } \\
\text { Class-II+ }\end{array}$ & $31.9 \pm 8.5$ & $28.8 \pm 8.2$ & $27.5 \pm 8.8$ & $32.2 \pm 10.0$ & $24.8 \pm 8.4$ \\
(P7/7) & & & & & \\
\hline
\end{tabular}

Data are mean $\pm \mathrm{SD} .{ }^{\mathrm{a}} n=3,{ }^{\mathrm{b}} n=5,{ }^{\mathrm{c}} n=4, \mathrm{ANOVA}=\mathrm{NS}$

\section{Immunohistochemistry}

Serial cryostat pancreas sections $(5 \mu \mathrm{m})$ were fixed in acetone for $30 \mathrm{~min}$ at room temperature and stained for $60 \mathrm{~min}$ with rat monoclonal antibodies P7/7 [10], culture supernatant at a $1: 2$ dilution in Tris Buffered Saline (TBS, pH 7.6), and AMT-13 (anti-IL2R, T. Diamanstein, Berlin, GDR), purified Ig from rat ascites at $5 \mu \mathrm{g} / \mathrm{ml}$ concentration. The $\mathrm{P} 7 / 7 \mathrm{MAb}$ recognises Class-II molecules of all tested haplotypes, including $b, \mathrm{~d}$ and $\mathrm{k}$ [10]. Sections were washed three times in TBS prior to further incubation for $30 \mathrm{~min}$ with peroxidase conjugated rabbit anti-rat Ig (Dako P162) at a 1:50 dilution in TBS with 1:10 normal mouse serum. Positive cells were then revealed using diaminobenzidine and hydrogen peroxide [15] and counterstained with Mayer's haematoxilin.

Five different sections were examined per pancreas for a total of at least 10 different islets. In infiltrated islets at least 200 lymphocytes were counted per islet and positive lymphocytes were expressed as percentage of total lymphocytes per islet.

\section{Results and discussion}

The results of our study are summarised in Table 1. The percentage of Class-II positive infiltrating cells found in the pancreata of NOD mice ranged 25-32\% between weeks 5 and 22 with no significant variations. In disagreement with recently published data by Hanafusa et al. [9] we have never observed Class-II expression on islet cells in NOD mice of any age (Figs. 1A, B). Two of the four mice of 22 weeks of age were newly diagnosed as diabetic and therefore, it is unlikely that these results can be explained by transient expression of Class-II on B cells present only at the time of onset of diabetes. Hanafusa et al. found Class-II positive islet cells (using mouse monoclonal anti-IA antibodies) in almost all pancreata from female mice and to a lesser extent in male NOD, in accordance with their incidence of diabetes. However, it is surprising that in most of these cases Class-II expression on islets preceded the lymphocytic infiltration, and also that $\mathrm{BALB} / \mathrm{c}$ and B10.GD non-diabetes prone mice had I-A positive islet cells. The authors suggested three possible explanations for this phenomenon; but they did not consider the possibility of a cross-reaction of their monoclonal antibodies with other tissue antigens. Alternatively, the technical differences between our methods and those of Hanafusa et al. might account for the discordant results. While we used cryostat sections and rat MAbs these authors used Bouin's fixed and paraffin embedded material and mouse MAbs. We never observed Class-II expression on islet cells in
BALB/c (Fig. 1C), B10.SCSN and CBA mice, but tissue macrophages (which express I-A antigens) as well as some splenocytes (data not shown) were stained with $\mathrm{P} 7 / 7$.

In a previous report [10] it has been shown that P7/7 stains not only cells of haemopoietic origin but also a few epithelial cells. Furthermore, the administration of IFN- $\gamma$ to B10 mice induced the expression of Class-II antigens in other epithelial cells but not in islet cells. Therefore it seems unlikely that B cells may express Class-II antigens which are not detected by our MAb.

Activated IL2R positive lymphocytes were constantly observed in all animals (Table 1 and Fig. 1D) but at any age their number was less than Class-II positive mononuclear cells.

Unlike human, mouse T lymphocytes do not express Class-II antigens following activation [11] with the exception, probably, of a small percentage of suppressor $T$ cells $[13,16]$. Therefore the I-A positive mononuclear cells infiltrating the islets in NOD mice cannot all be considered to be activated Tlymphocytes, in contrast with what has been reported previously by Miyazaki et al. [2]. These cells mainly represent an heterogeneous population of monocytes and B lymphocytes as also suggested by Kanazawa et al. [5]. Furthermore, the presence of a large monocytic infiltration of the pancreas has also been reported in $\mathrm{BB} / \mathrm{W}$ rats [17]. Since activated T lymphocytes and monocytes are distinct cell populations which play important roles in the pathogenesis of diabetes $[17,18]$ it is important that they are distinguished.

In conclusion, our data show that Class-II antigens in the pancreas of NOD mice are only expressed by infiltrating mononuclear cells which represent about $30 \%$ of total infiltrating cells. Activated IL2R positive T lymphocytes are less than $9 \%$ of infiltrating cells. Further investigations are required to clarify whether islet B cells can express Class-II antigens under any circumstances. At present our data suggest that they cannot; and in this respect the NOD mouse differs from the BB rat as an animal model for Type 1 diabetes.

Acknowledgements. This work was supported by a Grant from C. N. R. (International project 86.0012504 ). A. S. is a fellow of Istituto Pasteur, Fondazione "Cenci-Bolognetti", Italy. We wish to thank Dr. A. Hayward for useful discussion, Dr. T. Diamanstein for the AMT$13 \mathrm{MAb}$ provided and Ms. D. Rowe for immunocytochemical studies.

\section{References}

1. Foulis AK, Liddle CN, Farquharson MA, Richmond JA, Weir RS (1986) The histopathology of the pancreas in Type 1 (insulindependent) diabetes mellitus: a 25 year review of deaths in patients under 20 years of age in United Kingdom. Diabetologia 29: 267-274

2. Miyazaki A, Hanafusa T, Yamada K, Miyagawa J, Fujino-Kuri- 
hara H, Nakajima H, Nonaka K, Tarui S (1985) Predominance of T lymphocytes in pancreatic islets and spleen of prediabetic non obese diabetic (NOD) mice: a longitudinal study. Clin Exp Immunol 60: 622-630

3. Nakhooda F, Like AA, Chappel CI, Wei CN, Marliss EB (1978) The spontaneously diabetic Wistar rat (the "BB" rat). Diabetologia 14: 199-207

4. Dyrberg T, Poussier P, Nakhooda F, Marliss EB, Lernmark A (1984) Islet cell surface and lymphocyte antibodies often precede the spontaneous diabetes in the BB rat. Diabetologia 26: 159-165

5. Kanazawa Y, Komeda K, Sato S, Mori S, Akanuma K, Takaku F (1984) Nonobese-diabetic mice: immune mechanisms of pancreatic $\beta$-cell destruction. Diabetologia 27: 113-115

6. Bottazzo GF, Dean BM, McNally JM, MacKay EH, Swift PGF, Gamble DR (1985) In situ characterization of autoimmune phenomena and expression of HLA molecules in the pancreas in diabetic insulitis. N Engl J Med 313: 353-360

7. Foulis AK, Farquharson MA, Hardman R (1987) Abberant expression of Class II major histocompatibility complex molecules by B cells and hyperexpression of Class I major histocompatibility complex molecules by insulin containing islets in Type 1 (insulin-dependent) diabetes mellitus. Diabetologia 30:333-343

8. Dean BM, Walker R, Bone AJ, Baird JD, Cooke A (1985) Prediabetic $\mathrm{BB} / \mathrm{E}$ rat: lymphocyte subpopulations in the pancreatic infiltrate and expression of rat MHC class II molecules in endocrine cells. Diabetologia 28: 464-466

9. Hanafusa T, Fujino-Kurihara $H$, Miyazaki A, Yamada K, Nakajima H, Miyagawa J, Kono N, Tarui S (1987) Expression of class II major histocompatibility complex antigens on pancreatic $B$ cells in the NOD mouse. Diabetologia 30: 104-108

10. Momburg F, Koch N, Moller P, Moldenhauser G, Butcher G, Hammerling GJ (1986) Differential expression of Ia and Ia-associated invariant chain in mouse tissues after in vivo treatment with IFN- $\gamma$. J Immunol 136: 940-948

11. Flavell RA, Allen H, Burkly LC, Sherman DH, Waneck GL,
Widera $\mathrm{G}$ (1986) Molecular biology of the $\mathrm{H}-2$ histocompatibility complex. Science 233: 437-443

12. Triebel F, Deroquef S, Blanc C, Charron DJ, Debre P (1986) Expression of $\mathrm{MHC}$ class II and TAC antigens on IL2 activated human T cell clones that can stimulate in MLR, AMLR, PLT and can present antigens. Human Immunol 15: 302-305

13. Araneo BA, Yowell RL (1985) MHC-linked immune response suppression mediated by $T$ cells bearing I-A-encoded determinants. J Immunol 135: 73-79

14. Prochazka M, Leiter EH, Serreze DV, Coleman DL (1987) Three recessive loci required for insulin-dependent diabetes in nonobese diabetic mice. Science 237: 286-289

15. Rowe DJ, Isemberg DA, Beverley PCL (1983) Monoclonal antibodies to human leucocyte antigens in polymyositis and muscular dystrophy. Clin Exp Immunol 54: 327-336

16. Beverley PCL, Woody J, Dunkley M, Feldmann M, McKenzie I (1976) Separation of suppressor and killer T cells by surface phenotype. Nature 262: 465-467

17. Kiesel U, Oschilewski M, Kantwerk G, Maruta M, Hanenberg H, Treichel U, Kolb-Bachofen V, Hartung HP, Kolb H (1986) Essential role of macrophages in the development of Type 1 diabetes in $\mathrm{BB}$ rats. Transplant Proc 6: 1525-1527

18. Kolb H, Zielasek J, Treichel U, Freitag G, Wrann M, Kiesel U (1986) Recombinant interleukin 2 enhances spontaneous insulindependent diabetes in BB rats. Eur J Immunol 16: 209-212

Received: 10 September 1987

Dr. P. Pozzilli

Department of Diabetes and Immunogenetics

Dominion House

St. Bartholomew's Hospital

West Smithfield

London EC1A 7BE

UK 